\title{
An Analysis on Fragile People of a Local Government Strategic Between Malaysia and Thailand in Time of Covid-19 Pandemic
}

\author{
Non Naprathansuk ${ }^{a}$, Winit Pharcharuen ${ }^{b}$, Halimah Abdul Manaf $^{\mathrm{c}}$ \\ ${ }^{\mathbf{a}, \mathbf{b}}$ School of Administrative Studies, Maejo University Thailand \\ ${ }^{\mathbf{c}}$ School of Government Universiti Utara Malaysia \\ Email: ${ }^{a}$ nonnaprathansuk@ hotmail.com, ${ }^{\mathrm{b}}$ winit.phacharuen@gmail.com ${ }^{\mathrm{c}}$ imah@uum.edu.my
}

Article History: Received: 10 November 2020; Revised 12 January 2021 Accepted: 27 January 2021; Published online: 5 April 2021

\begin{abstract}
This article aimed to analyzed and compared on fragile people of a local government strategics between Malaysia and Thailand in time of Covid-19 pandemic. The methodology of this article was a qualitative approach based on the secondary data from case of Malaysia and Thailand. The finding of this article was Malaysia's local government has more independent and design different business and social strategies to help fragile people consist of community care initiative, homeless people assistance and business scheme opportunity for petty traders and hawkers rather than Thai's government that local government did not have fully autonomous authorities and independent from Thai government. Therefore, the contribution of this article up to enlighten the roles and functions of the local government as fundamental institution to assist and support the local fragile and vulnerable people in facing the pandemic crisis of COVID-19.
\end{abstract}

Keywords: Sustainability, fragile people, local government s, COVID-19, Malaysia, Thailand

\section{Introduction}

Fragile contexts are starting to be hit through the COVID-19 pandemic crisis. Most of these countries are insufficiently prepared to cope with the spread of the pandemic crisis and its consequences during the multiple dimensions of fragility. As with all disasters and crisis, COVID-19 is revealing the present day of socio-economic inequalities. The impact of the crisis is greater at the poorest, and poverty is increasingly more targeted on fragile and struggle-affected contexts. These days, the fragile people had been the most prone group to be tormented by the pandemic COVID-19. This group is closely relying on the day-to-day basis earnings with the aid of running a self-small business strategics to keep hold sustaining with their daily life routine.

As this crisis has erupted all the global, the South East Asian countries additionally not able to slip faraway from this pandemic disaster especially in Malaysia and Thailand which one of the much-affected nations in SouthEast Asian regions. The respective fragile people are undeniable that greatly have been affected which they powerless to preserve operating their day-by-day small business due to the curfew and movement control order strategics that has been carried out recently by the government. Both central and local government in those two respective countries has taken a high preventive measure in attempts of combatting the pandemic disaster by limiting the movement of their people on the out of the doors. That is; however, this study will be present process through narrowing the topic of the study by overviewing at micro-stage of local government in Malaysia and Thailand in their intervention of handling the disaster of pandemic COVID-19. Therefore, the purpose of accomplishing this study is to deliberately analyse the strategy that has been taken by the local government in Malaysia and Thailand to keep sustaining the fragile people keep ahead with their life throughout the pandemic COVID-19 crisis.

\section{The Concept Of Local Government.}

Sady (1962) referred local government as a small part of the political system in a nation-state or the federal system that is governed by the law and has considerable control of local affairs, including the powers to raise tax or labour. Later, [1] Hill (1974) described the local government as a unit system specified by the border region, legitimate identity, institutional structures, functions, and powers specified in general and specific positions, financial and other important autonomy[2]. In addition to that, Ayub (1978) describes local government as being run through a board or council in an area for the welfare and well-being of the citizen and acting responsibilities for a citizen residing within the place [3]. OECD (2001) later described local government organization as an organizational group unit whose monetary, legislative, and executive authority extends over to the smallest geographical regions that prominent for administrative and political functions [4].

From the given definitions above, Halimah (2012) and (Hussain, 2002) described local government may be the notion of as the local government' units or establishments of governance on the lowest tiers of authority in an area 
or a small vicinity, with a certain political and administration powers [5]-[6]. In Sady's (1962), Hill's (1974) and OECD (2001) definitions, extra emphasis is located on power, at the same time as the definition is given through [7]-[8]-[9], Ayub (1978) focuses greater on components of the services supplied through the local government. It implies that during local authorities, there are key critical factors, jurisdiction and services [10].

\section{The Functions Of The Local Government}

In Malaysia, the local government is the third degree of government after state and federal government, referred to as Pihak Berkuasa Tempatan (PBT) [11]-[12]-[13]-[14]. As stated inside the Federal constitution in 1957, the local governments are beneath the jurisdiction of the state government and the federal government. Underneath this constitution, the local government is one of the subjects reserved for the state government, and Clause 76 (4) of the constitution highlighted that the federal government has the authority to make legal guidelines to obtain equality in policy and regulation [15]. Because of this any policies and objectives decided via the federal government and the state ought to be generic and applied through all the local governments, except for the Federal territory issue to the minister in charge of the affairs of the Ministry of Housing and Local Government [16]. The below Figure 1 illustrated the Malaysian Local Government System that currently had been carried out in Malaysia.

Figure 1: Malaysian Local Government System

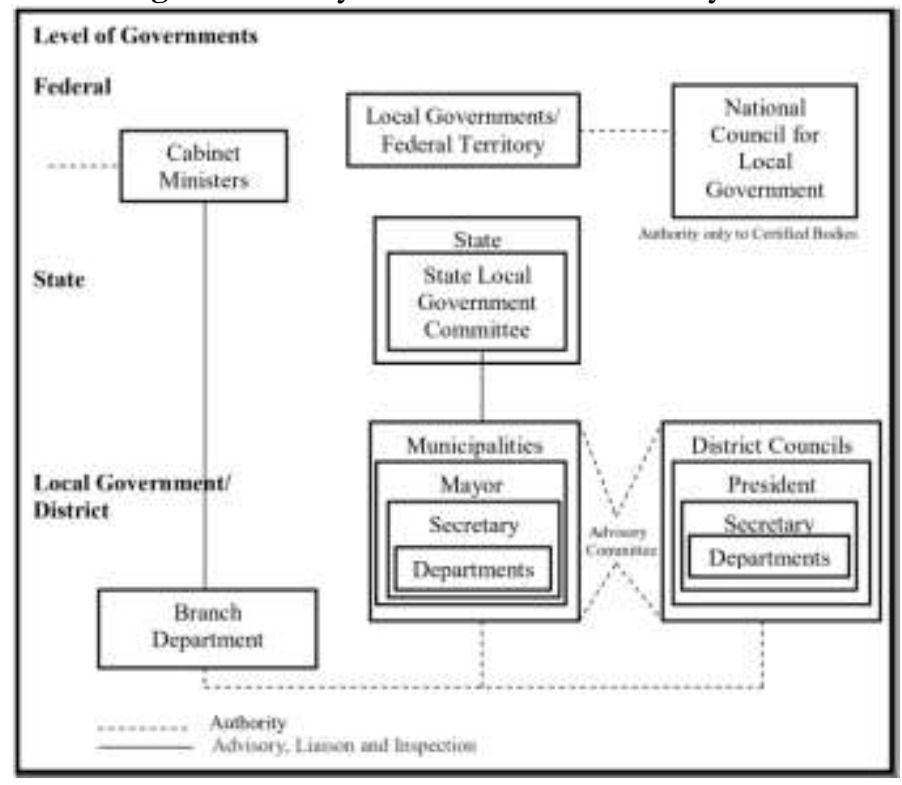

Source: Hussain (2002) [17].

Underneath the local government Act 171, the local governments in Malaysia have the strength to impose restricted taxes which include a tax assessment that may be a predominant source of organization earnings. The local government may additionally put into effect and implement via-laws for citizens local in the administrative place. With the aid, of-laws are as a solution to the issues that arise among the population neighbourhood. The Federal constitution of Malaysia restricts the exceptional power of governing the government local to the state government. Further to the constitutional provisions, a few parliamentary acts were formulated to regulate local government strategicss in Malaysia together with the Local Authorities Act (Act 171), Town and Country Planning Act 1976 (Act 172) and Street, Drainage and Building Act 1974 (Act 133) [18].

In line with Suhaiza, Suzei and Zarina (2017), the fundamental reference for local government legal guidelines in Malaysia is Local Government Act 171, at that is most influential in outlining forms, organizational structures, duties, and the obligation of the local government as an entire. On the same time, this act additionally outlines local governmental authority in three major areas, specifically, administration, finance, and function. Underneath Section 127, the Local Government Act of 1976 states that local government might also impose an assessment tax rate on their holdings beneath his administration. Tax revenues could be used to cover government spending locals which include acting duties, functions, and services to the locals. Tax assessments are a primary contributor to local revenue. The tax could be used to provide public utilities, to preserve the region management and additionally paid personnel emoluments. So, it truly is tax management assessment efficiency is an essential component in making sure that the respective local government agency is carried out a balanced annual budget for the incoming distribution of powers [19].

From this angle, the function of local government is within from the grassroots level of civil society to be overseeing the fragile and risk group to be affected of socio-economic downfall for the duration of this COVID-19 
pandemic disaster in Malaysia for. Local government might be the most significant governmental organizations which can be the closest to the local community and knew what the local community needs and seeks from the authorities. As for this, the function of the local government is to bridge the connectivity in between the local stage and the higher authorities of government, neither the federal nor the state. The local government is also accountable to inform to the federal and the state government in the needs of local people that need to be paying attention for.

Meanwhile, The Kingdom of Thailand is a constitutional monarchy under which the king considerable as a head of the state. However, the government is divided into three branches which are; the legislative branch: The National Assembly is composed of the Senate, the 150 members fully appointed upper house, and House of Representatives, the 350 member lower house. The executive branch consisting of the Prime Minister of Thailand who was elected by the National Assembly and other cabinet members of up to 35 people. The cabinet was appointed by the king on the advice of the prime minister. The prime minister is the head of government. The judiciary is independent of the executive and the legislative branches. The judiciary of Thailand is composed of four distinct systems: The Court of Justice system, the Administrative Court system, the Constitutional Court, and the military court.

Nonetheless, the local government in Thailand did not play the main role rather than central government. Also, the relationship between the central government and local government always plays a crucial role especially in terms of politics and fiscal. the fundamental problem is that the intergovernmental fiscal transfer is not designed as means of appropriately meeting the fiscal needs of transferred services and responsibilities [20]. Also, the local government always control and supervision under the Thai administration line. Therefore, consistence with decentralization concept, it is an important that central government ought to collaborate and fully decentralize authority and fiscal in time of the COVID-19 pandemic.

Thailand is a unitary state. It has traditionally employed a highly centralized form of government, in which most employees at provincial, district and sub-district levels are affiliated with central agencies and local communities are governed directly by officials appointed from Bangkok [21]. According to The Public Administration Act in 1991 was promulgated which laid down the new administration structure which are central, provincial, and local administrations [22]. There are three basic levels of public administration in Thailand: central, provincial, and local administration. The central administration consists of ministries. The provincial administration comes under the concept of deconcentrating, which means that the central government delegates some of its power and authority to its officers who work in provinces and districts, and the provincial administration consists of provinces, districts, minor districts, subdistricts (or Tambon) and villages. The local administration is based upon the concept of decentralization, which allows local people to participate in local affairs under concerned laws and regulations, and there are 2 types of local administrative organization: the general type (composed of Provincial Administration Organization, Municipalities, and Subdistrict Administration Organization); and the special type (consisted of Bangkok Metropolitan Administration and the City of Pattaya) [23]. The below figure 3 shown a basic level of Thai Public Administration that currently had been carried out in Thailand.

Figure 2: Thailand Local Government System

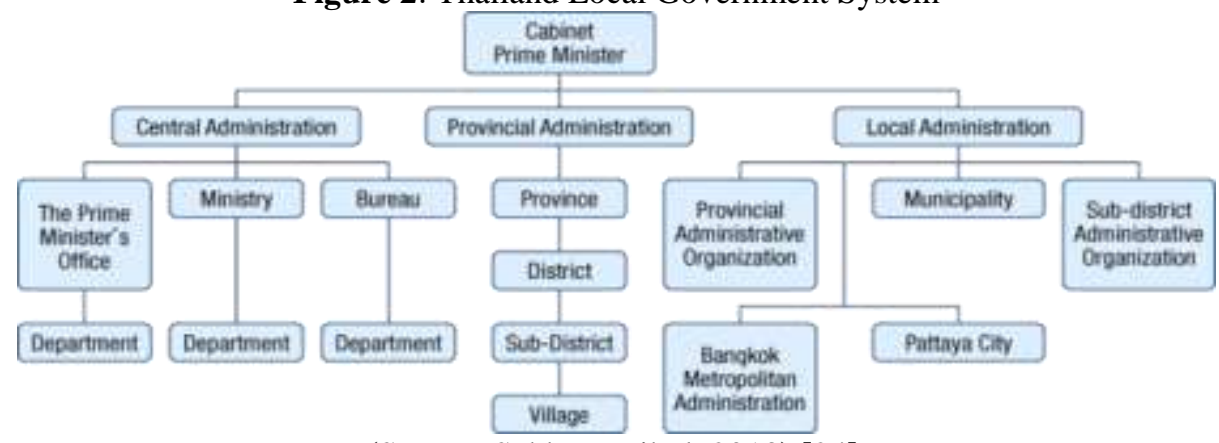

(Source: Sakkayarojkul, 2013) [24].

The purpose of decentralization to local administrative organizations (LAOs) is to decrease central government's mission and increase power to community and local administration. This is because the local administrative organizations (LAOs) were designed to be the main organization to provide public services. The local administrative organization (LAOs) must provide services that serve the needs of the people efficiently through the process of public participation [25]. Moreover, decentralization is certainly crucial policy both for central government and local government. Thus, decentralization policy has various perspectives to present. It needs to shift accountability, power, and financial capital from the central government to local government [26]. 
Notwithstanding, Fiscal decentralization is considered as a key element to improve public governance in Thailand. The most important feature of fiscal decentralization is the devolution of the central government's fiscal powers and responsibility to local governments in, among others, revenue collection, expenditure decision, and fiscal policy discretions. The central government also uses fiscal decentralization to enable local governments to improve efficiency and effectiveness in public services delivery that could also foster local accountability. Theoretically, central government's inadequate information on the needs of local people causes inefficiency in public services delivery across the country. The local governments are better informed on said needs and therefore they can address them more effectively than the central government [27].

Furthermore, civic consultation is a more meaningful approach to local participation, people can voice their ideas directly on local affairs through the provided channels in the decision-making process. The public and the authorities may have interactive dialogues over issues of concern [28]. Therefore, without a doubt, local government is a front-line organization that help create the efficient delivery pf public services and serve a local need especially Provincial Administrative Organization (PAO) municipality and Tambon Administrative Organization (TAO). PAO is the upper-tier which operates large-scale administrative duties and public services, while the municipally and TAO are the lower-tier which is responsible for small-scale duties [29].

In the meantime, COVID-19 pandemic disaster in Thailand is one of the most important case for Local Administrative Organization to mitigate the hunger and support the local people and fragile people in their area. In this case, PAO and TAO are closest government organization to support and sufficient information to local community needs in time of pandemic. However, the connectivity between the local level and higher level especially from the central need exchange information and provides the needs for local community nationwide.

\section{The Concept Of Fragile People}

The concept of people fragility may be varied throughout a multi-dimension angle. The issues of unemployment, frustration and violence amongst people, and the capability for them to change norms and values, in addition to aid development, are all exacerbated in conditions of struggle and fragility. Fragility is an alternatively indistinct concept deriving from the notion of 'fragile states', states with a constrained ability and/ or political will to provide simple services to the population [30]-[31]. Numerous social, monetary, and political instabilities characterized fragile contexts, and fragility is frequently linked to the presence, current conclusion, or threat of violent struggle. Even though a generalised period, it is significant to take note of nuances and the distinctiveness of every context of fragility [32]. Moreover, there are variations among experiences of emergencies, early recovery, and reconstruction, yet overlaps and downsides make clear demarcations hard.

From the World Bank's literature work in characterizing the fragility are associated with the figuring out which nations are experiencing specifically fragile conditions has been in impact since 2006 by focusing in large part on countries experiencing the outcomes of struggle and violence [33]. As the World Bank (2020) has also said the definition on the fragility as a crucial development task that threatens efforts to cease severe people poverty, affecting each low- and middle-income nations especially in the COVID-19 pandemic crisis. The world bank conceptual measure on the people fragility does no longer focus on health specifically alone, but it is identified in-associated with views of the governance and monetary-related challenges which identified present intense threats additionally to public and private health. The World Bank additionally introduced the context on fragility is probably from the angle of climate change, growing the people inequality, demographic change, new technology changes, illicit monetary flows and different global tendencies may additionally create a fragility risks on vulnerable low- and middle-income people at the end of the day. Each low- and middle-income people within several the nations are much likely to be suffering from a fragility crisis this day. [34]

Fragility can as well result in negative consequences which include the violence, the breakdowns of institutions, displacement, humanitarian crises, or different emergencies. At the same time as nevertheless conceptualizing the people fragility as a state- or country-stage phenomenon, the OECD expands on the World Bank country policy and institutional evaluation via focusing on varieties of fragility rather than just on states, which affect monetary, environmental, political, safety, health, and societal domains. OECD estimates imply that by 2030 , much likely $80 \%$ of the worldwide poor people will stay in contexts stricken by one or extra of the fragility crisis [35]; also, many stable and wealthy environments that fall into the middle-income country bracket are much likely to be in covered on this estimate [36]. Hence, with the aid of promoting this greater granular knowledge of fragility throughout a much wider pool of nations, the OECD hopes to set off a reflection by differentiated various strategies that needed to give a boost to the coping capacities of diversely fragile contexts among the people and globally.

\section{Methodology Of The Study}

This study is using the qualitative-based approaches and the collection of the data is based on the secondary data which is the researchers will be collecting the related important literary works from the local and international perspectives to overseeing the functionality of the related local government agencies in handling the pandemic crisis. While the collection of the data findings such as statistics, official reports and case studies from 
the relevant-local government's administration report that had been recently published via the newspaper, archives, mainstream media, social media, and some of the official documentation report from the respective local government that has been involved with some from the internet sources that much greatly contribute to the development of this respective study. In the context of Malaysia, the study is primarily based on the Kuala Lumpur City Hall (DBKL). For Thailand, the case took on the provincial level (PAO), Chiang Mai Provincial Administrative Organization and Chang Puak Sub-district (TAO level). After that content analysis used for analysed and interpreted on both cases.

\section{A Case Study On Malaysia}

Malaysia case study took place in Kuala Lumpur City Hall (KLCH), the Ministry of Federal Territories, had took the initiatives of introducing Community Care Initiative to help urban poor, B40 group, students, the homeless, petty traders, and hawkers to cope with the impact of the COVID-19 - 19 outbreaks. This initiative come with an allocation of RM 63,600,000.

As a basis, the initiative is looked as a function in helping citizens who stay and work in Kuala Lumpur, Putrajaya, and Labuan as they are in Federal Territories (FT). In addition, it also has its own focus on three main clusters who are front liners, patients, and patients under investigation (PUI) and citizens that include urban residents, B40, petty traders and hawkers. Other than that, the allocation being standardized with three main local government under FT, which Kuala Lumpur City Hall (DBKL), Putrajaya Corporation (PPj) and Labuan Corporation (PL) [37].

According to the Minister of Federal Territories, Tan Sri Annuar Musa, Malaysian Government always committed in giving reasonable helps to all of the homeless people [38]. In addition, he also adduced that they will be offered jobs on the factory and general fields and living places too after MCO be ended by Malaysian government. In the meantime, they will undergo several training and courses so that they are able to enter work field successfully [39]. On the part of DBKL itself, they already prepared for almost 1,000 vacancies for the people who want to work in Kuala Lumpur and at the same time, they do not have to become homeless anymore. What they need to do is by coming to DBKL or Department of Labour Malaysia branch Kuala Lumpur [40].

Thus, based on the efforts done by Ministry of Federal Territories together with DBKL, first group of the homeless consisted of 43 individuals had been accepted to work in Sitiawan, Perak whilst the others who only succeed in physical test and strainer test of Covid- 19 will get their job with DBKL itself [41]. Around 360 homeless already being sent to the training centre in Sepang for a month whilst another 60 being sent to Kuantan for attending courses and training for 3 months before they start working soon.

Based on the actions and efforts shown by Ministry of Federal Territories to curb and solve the homeless issues in Malaysia, it clearly shows that how serious they are in helping all the homeless people to live in a good life especially during this pandemic Covid-19. In the meantime, no actions contributed by DBKL can be forgotten because they also have given full contribution to make sure that all the homeless are safe. What can be perceived on this part of contribution is about the function delegated directly by Ministry of Federal Territories towards DBKL itself. As what can be seen, on the part of this homeless issue, they able to help all the homeless in Kuala Lumpur by providing the temporary placement for them and their daily needs. Other than that, DBKL together with Department of Labour Peninsular Malaysia Branch Kuala Lumpur had helped all the homeless in finding the jobs for them to continue their life in a good way and not living as a homeless anymore.

In the meantime, the petty traders and hawkers throughout the country including the one who work in Kuala Lumpur have faced the big impact on their businesses, as they are not able to run it to oblige with the Malaysian Government order which MCO. Concerning the petty traders and hawkers who run their businesses in Kuala Lumpur, Ministry of Federal Territories already took some measurements and initiatives to help lighting their burdens so that they can continue surviving their life during the pandemic. Like the homeless who have special allocation under Community Care Initiatives, Ministry of Federal Territories also gave full attention towards petty traders and hawkers in helping them. Thus, under Community Care Initiatives, Ministry of Federal Territories have allocated for RM500 one - off payment to all of them who run their business in places like Bazaria Larut Malam, night markets, open markets, food trucks, roadside stalls, agricultural markets, and kiosks, which sum up to RM 11,800,000. Other than that, 6,000 petty traders and hawkers in Kuala Lumpur also received an exemption for three months of lease payment from DBKL and for those who run it in Putrajaya; they will get the rent exemption payment for two months from Putrajaya Corporation [42].

Concerning about petty traders and hawkers in Kuala Lumpur, DBKL had took several actions to help them in running their business around Kuala Lumpur smoothly. By referring to the official portal of DBKL itself, DBKL already provided the strategic location for all the petty traders and hawkers. As a basis, DBKL have provided 100 strategic locations, which consists of 2,053 of stalls that can be fit in all the locations and it is very convenience to for the hawkers and the customers, as it is clean, comfortable, and orderly. In the meantime, the facilities provided by DBKL is offered to the Kuala Lumpur citizens especially for young generations to start venturing their own food business. About the location, DBKL already categorized all of it into four main parts which DBKL Hawker Centres, Private Hawker Centres, DBKL Kiosk and DBKL Locked Stalls. The data is shown as below: 


\begin{tabular}{|l|c|c|}
\hline Section & Total Location & Total Stalls \\
\hline DBKL Hawkers Centres & 44 & 1154 \\
\hline Private Hawkers Centres & 51 & 784 \\
\hline DBKL Kiosk & 3 & 93 \\
\hline DBKL Locked Stalls & 2 & 22 \\
\hline
\end{tabular}

Source: Official Portal of Kuala Lumpur City Hall, 2020[43].

After that, during the pandemic Covid-19, it also gives new starts for the residents of Kuala Lumpur especially because, other than curb the spreadness of Covid -19, DBKL already took some actions in controlling and stopping the activities of illegal foreign hawkers who run their business around Kuala Lumpur. According to Muhammad Aminuraliff (2020), Mayor of DBKL, Datuk Nor Hisyam Ahmad Dahlan already gave out the order of no illegal foreign hawkers run their business especially in the hawking field in Kuala Lumpur anymore. In the meantime, he also added that DBKL would enhance the current by laws like Wholesale Markets (Federal Territories) 2002, Markets (Federal Territories) 2016 and Licensing of Hawkers (Federal Territories) 2016 to stop all of their activities too. The seriousness of DBKL in solving these illegal foreign workers could be seen in several actions done [44].

Another effort of providing trade lots at big shopping complex for the youths who just want to start their business clearly shows that how DBKL want to give the best facilities for them and a helping them in generating income for their daily life too. As a basis, youths are the generation that cannot be left behind as they are the next generation that will bring the bright future for Malaysia. Other than that, this effort also is one of the initiatives by DBKL concerning about giving the best and reasonable help so that they can learn new things about business besides generating incomes for their own. Then, DBKL also has provided trade lots for the Bumiputera who lost their jobs due to Covid-19 outbreaks are another initiative that should be commended too. This is because instead of just giving helps on the monetary and other daily needs, DBKL encourage them to put some efforts in earning some money to survive. On the other hand, it will quash out the statement of Malaysian people are lazy to work and they can have new plans for their future with the new norms of life.

\section{A Case Study In Thailand}

Since the COVID-19 pandemic spread nationwide, The Thai government urged to lock down the whole country used a curfew period from 10.00 p.m. to 4.00 a.m. The Thai government has declared a national state of emergency in last week of March 2020. This emergency decree gives the Prime Minister wide-ranging powers to use as he deems appropriate, including the ability: 1) To ban people from leaving their houses or accommodation during specific time periods unless permission has been granted by authorities. In order words, to impose a curfew. 2) To prohibit public gatherings 3) To prohibit the dissemination of reports or distorted news which may lead to public panic. In other words, news censorship. 4) To prohibit the use of or entry to buildings. 5) To evacuate people from any area for public safety or to prohibit people from entering designated areas [45].

Moreover, the emergency decree impacted to Thai people daily life also, many stores, shops, hotels, and restaurants in service sectors have been suspended. For the homeless people, government statistics suggest Thailand has approximately 2,700 homeless people, likely a significant undercount in a nation of around 69 million [46]. The lockdown and empty streets mean fewer opportunities for homeless people to earn money. Also, the poor have found themselves facing increasing economic hardship since the government enforced social distancing measures and travel restrictions to flatten the curve of transmission. They survive off cheap food from street vendors, street stalls at markets or mobile food trucks -- many of which have suspended strategies or closed because of the government's restrictions on activities and movement [47]. In addition, they face stigmatization and accusations of negligently spreading the virus, as well as disobeying government orders. Government-run shelters are often overcrowded, without sufficient space required for physical distancing, and far from areas homeless people know and frequent, so they are reluctant to go.

This fragile people have no opportunity to get a better condition since their jobless in covid-19 pandemic across nationwide and defamed by the emergency decree. The only urgent solution while the whole country was locked down was 5,000-baht handouts over three months for 10 million households affected by the economic impact of Covid-19. The handout is worth 150 billion baht and it will come from the one-trillion-baht loan the government is seeks to acquire to finance its Covid-19 economic relief programs [48].

Therefore, the central government solution is insufficient to handle homeless people or fragile groups due to the limited of state revenue. The centralization of power from the Thai government which did not decentralized the power and revenue to local one thus, the remedy of 5,000-baht handouts over will be shortage faster and it does not sustain in the long run if the vaccine did not use for early next year.

Meanwhile, local government in Thailand did not have enough budget to help the fragile people and did not have authorities to provide some aids as well. Because of the government declared the emergency decree which was the power in country has been in prime minister hand only. All the solution just came direct from the 
government. However. It had some little things that the local government did with the local community such as provided free foods and free masks.

For the example, villagers in Chang Puak Sub-district (TAO level) have come together to make masks to give out for free to other members of the community. These masks will be handed out to people who need them in the Chang Puak community. The group is currently producing 200 masks per day including normal cloth masks and a higher-grade mask which will be handed out to officials and personnel with higher risk of infection [49]. Moreover, on the provincial level (PAO), Chiang Mai Provincial Administrative Organization have gathered to distributed to people provided food. they shall give out lunch boxes to the public for 15 days.

However, the real deal that Thai people can handle the corona-19 pandemic is Thai volunteers in each community and private organization rather than the central or local government. For example, The Central Group, established the "Food Sharing for Love" project to create collective actions for collective impacts. The project is hosted and implemented in collaboration with a local partner organization, the Doi Inthanon Conservation Trust Fund Foundation. The foundation is seeking food donations and raising funds to source various produce like herbs, vegetables, and fruits directly from the FLR349 project's farmers and its local organic farmers network that are struggling due to the market closures and supply chain collapse. Distribution of the food is systematic and comprehensive, reaching marginal communities that have trouble accessing food all around Chiangmai. Since the initiative initiation on the 20th of April 2020, a significant amount of food and funds have already been donated from the Central Group, local business companies, and many individuals. The delivery of products is carried out by a local logistic company, Nim See Seng, for free of charge [50].

Furthermore, there are some people cooperate with the provincial level which needs to the civil servants take an action to distribute aids for community such as the governor of Chiang Mai received numerous donations in front of the provincial hall this afternoon with dried food donated by the Consular Corps of Chiang Mai and rice and other food donated by the Royal Project as well as masks and survival packs donated by the Lanna Thai Women Association [51]. Also, normally people offer food to monks to make merit, but during this time of crisis some temples have started giving food to people who have lost their jobs [52].

Therefore, without a doubt the central government control power and budget in their hand without decentralized power and budget to local government caused a fragile group or poor people get life harder than use to be. the shortage of revenue and the government solution which is hand out 5,000 baht for three months seems sustain in the long run. The sustainable solution is the central government needs to decentralize their power and budget to local government which is closet to fragile people or the poor one. In Thailand case, the lesson to learn is both local government and community can tackle the problem by cooperate each other and could help fragile people and poor are directly and just in time. We must admit that the covid-19 pandemic shown us that the power of local and community are the best solution to against a serious problem and situation rather than the central government control. Finally, decentralize power and revenue are the best answer to governance and administration for a sustainability to the people.

\section{Conclusion}

Covid-19 pandemic created a vast catastrophe in every dimension especially strongly impact to fragile people, however, to tackle the problems local government is the key player in this serious situation. In Malaysia case, local government seemed to be a main role for handle to support fragile people in the meantime of covid-19 pandemic.

Since the central government ordered to lock down the country, fragile people such as homeless, petty traders and hawkers are insufficient income and live their life as normal. They struggled and suffered from the lock down order. Therefore, in Kuala Lumpur, DBKL as a case study shown that they took a quick actioned to all the homeless in Kuala Lumpur by providing the temporary placement for them and their daily needs. Also, the DBKL provided 100 strategic locations, which consists of 2,053 of stalls that can be fit in all the locations and DBKL offered to the Kuala Lumpur citizens especially for young generations to start venturing their own food business. About the location, DBKL already categorized all of it into four main parts which DBKL Hawker Centres, Private Hawker Centres, DBKL Kiosk and DBKL Locked Stalls. Moreover, DBKL provided trade lots at big shopping complex for the youths who just want to start their business.

On the other hand, in Thailand case. It seemed to lack of the authority to take an abrupt action to support fragile people. The main reason was that Thai government had declared a national state of emergency. Hence, the central government of Thailand was a direct authority to took control the whole country without given local government authority to handle in their community. However, there were many local governments tried to support and handle fragile people on their own ways. In this case it tool couple local government to studied which were Chang Puak Sub-district (TAO level) and Chiang Mai Provincial Administrative Organization (PAO) level. They provided free foods, free masks, and lunch boxes for their community and fragile people. Indeed, the private sector and volunteers were the key to support fragile people rather than local government that they were looking food donations and raised funds. Therefore, Malaysia's local government has more independent and design different business and social strategies to help fragile people consist of community care initiative, homeless 
people assistance and business scheme opportunity for petty traders and hawkers especially for a young generation. They cooperated with the central government rather than Thai's government that local government did not have fully autonomous authorities and independent from Thai government. Thai's local government had to follow the central government especially a state of emergency that strongly order. While the private sector and volunteers were key rather than both central and local governments in Thailand. This obviously outcomes shown that Thai government lacked fine strategy and insufficient resources to support fragile people nationwide. The government did not trust another sector and tried to solve the problems on their own with untrust no one. In contrast with Malaysia's government that the Ministry of Federal Territories, had took the initiatives of introducing Community Care Initiative and cooperated with local government that made fragile people could relief and comfort to support in both place and food also upgrade their skill for the future.

Finally, the contribution of this article up to enlighten the roles and functions of the local government as fundamental institution rather than centralized power to assist and support the local fragile and vulnerable people in facing the pandemic crisis of COVID-19.

\section{References}

Sady, E. J. (1962), "Improvement of Local Government and Administration for 1962 Development Purpose" Journal of Local Administration Overseas, July: pp.135- 148.

Hill, D. (1974). Democratic Theory and Local Government. Plurabelle Books Ltd (Cambridge, United Kingdom). ISBN 10: 0043520529 / ISBN 13: 9780043520529.

Ayub, A. (1978). "Cara Pemerintahan Tanah Melayu (1957-1963)," Kuala Lumpur: Dewan Bahasa dan Pustaka.Bangkok Post. (2020, April 29). Cabinet agrees to widen govt cash aid. Retrieved from BangkokPost.com: https://www.bangkokpost.com/thailand/general/1909452/cabinet-agrees-to-widen-govt-cash-aid

OECD. (2001). Local Government. Glossary of Statistical Terms. Retrieved from https://stats.oecd.org/glossary/detail.asp?ID $=1550$.

Halimah, A. M. (2012). The Influence of Knowledge Sharing on Performance among Malaysian Public Sector Managers and the Moderating Role of Individual Personality. PhD Thesis. The University of Hull, United Kingdom. Retrieved from https://hydra.hull.ac.uk/resources/hull:6378.

Hussain, A. A. (2002). Kerajaan Tempatan: Teori dan Peranan di Malaysia, Kuala

Lumpur: Dewan Bahasa dan Pustaka.

Sady, E. J. (1962), "Improvement of Local Government and Administration for 1962 Development Purpose" Journal of Local Administration Overseas, July: pp.135- 148.

Hill, D. (1974). Ibid

OECD. (2001). Ibid

Ayub, A. (1978). Ibid

Hussain, A. A. (2002). Ibid

Norris, M. W. (1980). Local Government in Peninsular Malaysia, England: Gower Publishing.

Nooi, P. S. (1997). Financing Local Government in Malaysia, University of Malaya Press: Kuala Lumpur.

Nooi, P. S. (2008). "Decentralisation or Recentralisation? Trends in Local Government

in Malaysia" Commonwealth Journal of Local Governance, No.1: pp. 126-132.

Ineh, A. K. (1975), Penyusunan Semula Penguasa-penguasa Tempatan di Semenanjung

Malaysia, Seminar Kebangsaan Kerajaan Tempatan, 30 Jun- 4Julai, Kuala Lumpur.

Hussain, A. A. (2002). Ibid

Hussain, A. A. (2002). Ibid

Siew, T. T. (2006). Electronic Local Authority Management System. Malaysian Institute of Planners in Planning Malaysia Journal Planning Malaysia Journal. Volume 3; doi:10.21837/pmjournal.v3.i1.45.

Suhaiza, N. M, K., Suzei, M. N. \& Zarina, M. Z. (2017). Konsep Pentadbiran Kerajaan Tempatan di Malaysia: Kajian Terhadap Pemahaman Pelajar Pentadbiran Awam (Local Government Administration Concept in Malaysia: Review On Public Administration Students Understanding). Journal of Global Business and Social Entrepreneurship (GBSE) Vol. 3: No. 7. Page 98-108. eISSN 24621714.

Fumio Nagai, N. M. (2008). Local Government in Thailand-Analysis of the Local Administrative Organization Survey. Chiba, Japan: Institute of Development Economics, Japan External trade Organization.

Bank, A. D. (1999). Governance in Thailand: Challences, Issues and prospects. Bangkok: Asian Development Bank.

Chayabutra, C. (1997). Local Government in Thailand. Bangkok: The Local Affairs Press Department of Local Administration.

Sakkayarojkul, O. (2013, March 13). An OverView of Spatial Policy in Asian and European Countries. Retrieved from National Spatial Planning and Regional policy Bureau, Ministry of Land, Infrastructure, Transport and Tourism (MLIT): https://www.mlit.go.jp/kokudokeikaku/international/spw/general/thailand/index_e.htm

Sakkayarojkul, O. (2013). Ibid

Puang-ngam, K. (2017). Assement of Local Admninistrative Organization with Good Governance. Social Science Asia, 30-40.

Krutchon, T. (2015). Conceptual Framework of Decentralization Policy: A Case of Local Government in Thailand. Jurnal Social Ilmu Politik Universitas Hasanuddin, 47-57. 
Laovakul, S. V. (2010). "Progress of Fiscal Decenteralization in Thailand", Impacts \& Challenges of Decentralization Policy towards Democratization and development (A Comparative between Thailand and Indonesia). International Joint Seminar (pp. 1-36). Yogyakarta: University of Muhammadiyah.

Krueathep, W. (2004). Local Government Initaitives in Thailand : Case and Lessons Learned . Asia Pacific Journal of Public Administration, 217-239.

United Nations Development Programme, T. a. (2009). Capacity Building and Civic Education on Support of Decentralisation and Local Governance in Thailand. Bangkok: United Nations Development Programme.

OECD-DAC. (2008). Concepts and Dilemmas of State-building in Fragile Situations: From Fragility to Resilience. OECD-DAC Discussion Paper.

INEE. (2011). Education for crisis-affected youth: a literature review, INEE. Task force for crisis affected youth and adolescence.

INEE. (2010). The multiple faces of education in conflict-affected and fragile contexts. The working group on education and fragility, INEE. Paris: UNESCO-IIEP.

World Bank. (2016). Information Note: The World Bank Group's Harmonized List of Fragile Situations. http://pubdocs.worldbank.org/en/586581437416356109/FCS-List-FY16-Information-Note.pdf. Accessed on 29th June 2020.

World Bank. (2020). Helping Countries Navigate a Volatile Environment. Fragility, Conflict \& Violence. https://www.worldbank.org/en/topic/fragilityconflictviolence/overview. Accessed on 1st July 2020.

OECD (2018). States of Fragility 2018. doi: 10.1787/9789264302075-en.

OECD. (2016). States of Fragility 2016: Understanding Violence. doi: 10.1787/9789264267213-en.

BH ONLINE. (2020). Inisiatif Wilayah Cakna diselaras, tawaran lebih baik - Annuar. (2020, March 28). BH ONLINE. Retrieved from http://www.bhplus.com.my/berita/nasional/2020/03/670250/inisiatif-wilayah-caknadiselaras-tawaran-lebih-baik-annuar

Nur Farhana, Norafiza Jaafar \& Muhammad Aminuraliff. (2020, June 15). DBKL tutup 127 premis warga asing. Sinar Harian. Retrieved from Artikel Penuh : https://www.sinarharian.com.my /article/87806/LAPORAN-KHAS/DBKLtutup-127-premis-warga-asing

Norafiza Jaafar. (2020, May 12). Kumpulan pertama gelandangan bekerja di Sitiawan. Sinar Harian. Retrieved from https://www.sinarharian.com.my/article/83244/EDISI/Selangor-KL/Kumpulan-pertama-gelandangan-bekerja-diSitiawan

Sinar Harian. (2020). Kerajaan komited pastikan tiada kembali jadi gelandangan. (2020, June 18). Sinar Harian. Retrieved from https://www.sinarharian.com.my/article/88368/BERITA/Nasional/Kerajaan-komited-pastikantiada-kembali-jadi-gelandangan-Annuar-Musa

Norafiza Jaafar. (2020). Ibid

The Star. (2020). Govt assistance for FT residents. (2020, April 17). The Star. Retrieved from https:/www.thestar.com.my/news/nation/2020/04/17/govt-assistance-for-ft-residents

$\begin{array}{ccccccl}\text { Official Portal } & \text { of } & \text { Kuala } & \text { Lumpur } & \text { City } & \text { Hall, } & 2020 .\end{array}$ https://www.dbkl.gov.my/?option=com_content\&view=category\&id=46\&lang=en

Muhammad Aminuraliff. (2020, May 6). DBKL tegas pastikan tiada warga asing berniaga. Sinar Harian. Retrieved from https://www.sinarharian.com.my/article/82302/EDISI/Selangor-KL/DBKL-tegas-pastikan-tiada-warga-asingberniaga

ThaiPBS. (2020, March 24). Thai government declares COVID-19 state of emergency. Retrieved from https://www.thaipbsworld.com/: $\quad$ https://www.thaipbsworld.com/covid-19-government-to-impose-state-ofemergency/

Phasuk, S. (2020, April 24). Covid-19 Curfew Arrests of Thailand's Homeless. Retrieved from Human Rights Watch: https://www.hrw.org/news/2020/04/24/covid-19-curfew-arrests-thailands-homeless

Wangkiat, P. (2020, April 13). Virus fight sees impoverished go hungry. Retrieved from BangkokPost.com: https://www.bangkokpost.com/opinion/opinion/1898460/virus-fight-sees-impoverished-go-hungry

BangkokPost. (2020, March 29). People step up to lend a helping hand. Retrieved from BangkokPost.com: https://www.bangkokpost.com/thailand/special-reports/1888480

City News. (2020, March 27). Community comes together to sew masks. Retrieved from https://www.chiangmaicitylife.com/:https://www.chiangmaicitylife.com/citynews/covid-19/community-comestogether-to-sew-masks/

wwf. (2020, April 23). FLR349 supports marginalised communities during COVID-19 pandemic fallout. Retrieved from https://www.wwf.or.th: https://www.wwf.or.th/en/our_news/news/?uNewsID=362635

CityNews. (2020, April 20). Governor passes on donations to the needy. Retrieved from https://www.chiangmaicitylife.com/: $\quad$ https://www.chiangmaicitylife.com/citynews/local/governor-passes-ondonations-to-the-needy/BangkokPost. (2020). Ibid 